\title{
ノート 超低硬度用硬度計と定圧荷重器の関係について
}

\author{
(平成 10 年 8 月 25 日受理)
}

\section{川崎 弘志*・長塚 和彦*}

\section{1. 緒}

さきにJIS K 6253-1997 のタイプEデュロメー 夕（日本ゴム協会標準規格 (SRIS) 0101-1968 「膨張ゴムの物理試験方法」のスプリング硬さ試 験機と同じ)で 10 度以下という超低硬度試料の測 定可能な新規硬度計 (以下, CSR 2 型硬度計とい う.）を提案した1).

CSR 2 型硬度計では再現性のある測定デー夕 を得るために補助具(定圧・定速荷重器)の使用が 不可欠であるので, 定圧荷重器の使用に関し測定 データに影響を及ぼす事項について調査, 検討し た結果を報告する。

定圧荷重器において測定デー夕に影響を及ぼす と考えられる要因は以下のとおりである.

1 ) 測定荷重 (測定圧)の大小

2) 降下速度 1 (硬度計の押針が試料に接触す るまで)

3 ) 降下速度 2 (硬度計の押針が試料に接触し た後)

\section{2. 実}

\section{験}

\section{1 ゴム硬度計用定圧荷重器}

定圧荷重器は市販の以下のものを用いた。

1) 油圧ダンパー式定圧荷重器*1)

2 ) エアーダンパー式定圧荷重器*2)

\section{2 ゴム試料}

2.2.1 材質 付加型シリコーンゴム(硬さ：夕

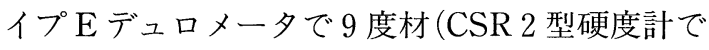
38 度材).

※本材質はJIS A 硬度計(JIS K 6301-1995)で は 0 度であり測定不能.

2.2.2 試料のサイズ $50 \times 70 \times 6 \mathrm{~mm}$ ( 2 枚重

\footnotetext{
*株式会社 荒井製作所

（テ124-8566 東京都葛飾区堀切3-30-1）
}

\section{ねで厚さ $12 \mathrm{~mm}$ とした）}

\section{3 試験結果のまとめ方}

試験結果は 5 回の測定值の中央值(整数位)

\section{3 . 結果}

\section{1 測定圧の確認}

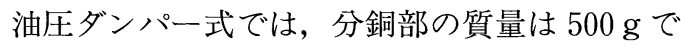
あり硬度計自体の質量が約 $250 \mathrm{~g}$ であるから, 全 体で $7.35 \mathrm{~N}$ (750 gf)の荷重がかかるはずである が，ひずみゲージで実測してみると Fig. 1 に示 したように硬度計先端の押針にかかる荷重は $5 \mathrm{~N}$ 近傍になっている。これはダンパー内のシャフト とパッキンの間にフリクションロスが約 $250 \mathrm{gf}$ あるため相殺されているものと考えられる.エア ーダンパー式では分銅を取りはずした状態で硬度 計の質量込みで $5 \mathrm{~N}$ の測定荷重になるように設 計されており，実測值もその值を示している。

\section{2 測定圧(荷重)の影響}

CSR 2 硬度計では超低硬度が測定できるよう にスプリングより針先に加わる荷重がタイプ E デュロメータの約 $1 / 2$ の $4.32 \mathrm{~N}$ (455 gf) で目盛 が 100 度になるようにスプリング荷重を落として 設定されている。このため硬度計の押針先端に最 低 $4.32 \mathrm{~N}$ の荷重を加える必要がある。ゆえに通 常は測定荷重を $5 \mathrm{~N}$ 設定にしているわけである が，更に分銅を載せて測定荷重を $9.8 \mathrm{~N}$ (1 kgf) になるまで変量して測ってみると Table 1 に示 したように油圧ダンパー式でもエアーダンパー式 も荷重が増すほど測定值が高くなる。このことは 超低硬度の試料においても粘弾性挙動での弾性率

*1) (侏)テクロック製ゴム硬度計用定圧荷重器(型式：GS710)の頭部分銅部を $1 \mathrm{~kg}$ から $500 \mathrm{~g}$ に改造したもの. 測定荷重は5N (実測值).

*2) 高分子計器(侏)製ゴム硬度計用定圧荷重器 (型式 : CL150)に軽量ジョイントを取付けたもの. フレキシブル ジョイントなし．測定荷重は $5 \mathrm{~N}$ (実測值). 


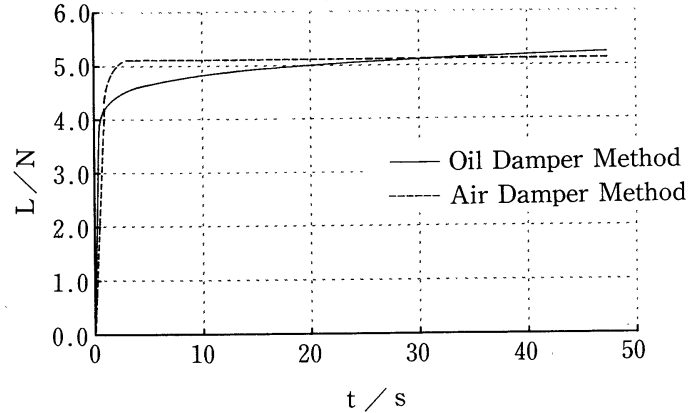

Fig. 1 Load growth curve against time at the tip of indentor. Solid and broken lines denote the curves by the methods with oil-damper and air -damper, respectively.

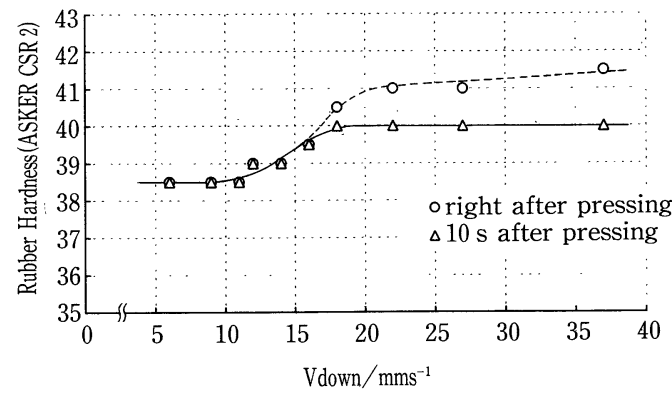

Fig. 2 Down speed, Vdown, dependence of the rubber hardness measured with oil-damper method.

Table 1 Effects of total load on rubber hardness in oil-damper and air-damper methods

\begin{tabular}{r|c|c|c}
\hline & \multicolumn{4}{|c}{ rubber hardness } \\
\hline total $\operatorname{load}(\mathrm{N})$ & 5 & 7.5 & 9.8 \\
\hline oil-damper method(Type $: \mathrm{GS}-710)$ & 38 & 39 & 40 \\
\hline air-damper method(Type : CL-150) & 36 & 38 & 41 \\
\hline
\end{tabular}

Note 1) Down speed of oil/air-damper: $11 \mathrm{~mm} / \mathrm{s}$

Note 2 ) Hardness is measured by new hardness tester for super low hardness specimen, Type CSR2 (see text).

の寄与が意外に大きいことを意味している.

\section{3 降下速度 1 の影響}

油圧ダンパー式定圧荷重器を用い，降下速度を 変更して測定した結果を Fig. 2 に示す.

このデータから，降下速度の速い領域では降下 直後と 10 秒後では測定值に差が見られる.これ は超低硬度試料においても応力緩和の性質がある ことを示している. 降下速度が $15 \mathrm{~mm} / \mathrm{s}$ (移動距 離 $11 \mathrm{~mm}$ で 0.7 秒) より遅くなると直後と 10 秒 後の差が見られなくなり安定した測定值が得られ る. 以上のことから, 実際の硬度測定作業では降 下速度を 9 13 mm/s (移動距離 $11 \mathrm{~mm}$ で $1.0 \pm$ 0.2 秒)に設定すると比較的安定した結果が得ら れる。

\section{4 降下速度 2 の影響}

ゴム硬度の測定において，硬度計先端の押針が 試料面に接触後の降下速度, いい換えれば荷重の かかり方はゴム硬度の測定值に大きく影響する。

Fig. 1 に示したデータから，エアーダンパー式で
は押し針先端に荷重がかかった直後に全荷重がか かるのに対し, 油圧ダンパー式では徐々に試料に 荷重がかかることがわかる，実際にゴム硬度を測 定したデータ(Table 1 に示した総荷重 $5 \mathrm{~N}$ 時) をみると意外にもエアーダンパー式のほうが油圧 ダンパー式より実測值で 2 度低い結果となった。

\section{4. 考}

察

圧力の負荷方式が油圧か空気圧かで硬度測定值 が異なるのは超低硬度試料においては粘性率の影 響を大きく受けているためと思われる。これらの ことから超低硬度ゴムの硬度測定には測定荷重を 定めること，降下速度 1 を一定にすること以外に 測定荷重の負荷方式を定める必要があるといえ る.

\section{引 用 文 献}

1）川崎弘志：日ゴム協誌，69，516(1996) 